\title{
Select bibliography
}

\section{Congregation and diocesan archives}

The archives used for this book are private archives and vary in the extent of their organisation, classification and cataloguing. Some archives have not classified or catalogued all their contents, so precise document reference numbers or descriptions are not available. In those cases, I have indicated a brief description of the item in place of a document reference number.

Dates of publication and authors are noted where known; however, many documents in the archives are not dated, nor are their authors noted. Much of the published material of the nineteenth century, such as books of necrologies, biographies, customaries and guides, was privately printed by an individual congregation and distributed within the congregation. This privately published material is included in this section of the bibliography, and does not include a publisher if privately published, or the date of publication if the date is not known.

\section{Archdiocesan Archives of Liverpool}

Chancellors' Records, Series 8, III, Male \& Female Religious Orders

Chancellors' Records, Series 8, IV, Male \& Female Religious Orders

Female Orders \& Convents - General

Female Orders \& Convents - Specific Congregations

Ceremonial for the Reception and Profession of the Religious Sisters of Mercy

(Dublin: Browne \& Noland, 1894)

\section{Archives of the Sisters of Mercy, Midhurst}

Profession Register of the Sisters of

Mercy Annals

\section{Archives of the Sisters of Mercy, Sunderland}

Profession Register of the Sisters of

Mercy Annals 
CSJP: Archives of the Congregation of St Joseph of Peace

Register of Professed Sisters

Columba Moran, 'History of the S.H. Convent'

'Lest We Forget'

Ferguson, Sr Catherine, 'Sisters of St Joseph of Peace: History of the Sacred Heart

Province, 1884-1984', 1983

'A Look at the Evidence: The Nun of Kenmare \& Knock 1881-1883'

(Dublin, 1991)

'The Founding and Growth of the Sisters of St Joseph of Peace' (Leicester, 1984)

Reflections and Counsels of Mother M. Evangelista to her Spiritual Children (1963)

\section{DC: Archives of the Daughters of Charity of St Vincent de Paul, Mill Hill, London}

Register of Sisters of the British Province

10: Personnel Records, 'Lives of Sisters'

11: House Records, 'Houses'

Box 1, no. 2: 'Seminary Remarks'

Box 1, no. 10: 'Seminary Particulars', 1889-1917

\section{Notes on Deceased Sisters}

'J.M.J. Rules of the Daughters of Charity Servants of the Poor Sick, Common Rules of the Daughters of Charity', 1920 (transcribed version of Règles Communes des filles de la Charité, 1867)

'Remarks on the Life of Sister Mary Langdale'

'Sr. Etheldreda Fitzalan Howard'

Pioneer Sisters of Charity of Saint Vincent de Paul in Great Britain and Ireland (1955)

\section{DHM: Daughters of the Heart of Mary Archives, Wimbledon, London}

Register of Members of the Kensington Reunion and Wimbledon

C3 'Acts of Superior Authority 1858-1920'

C3 'London Diary: Clapham'

C3 'Provincial Council Meetings'

C4 'Death Notices English/Irish Provinces - Before 1900'

Special collection 'Old Letters and Documents'

Annals, vols I-IV

Rule of Conduct for the Daughters of the Heart of Mary (Roehampton: James

Stanley, 1896) 
Constitutions des filles due coeur de Marie

Constitutions et Règlements de Conduite des Filles du Coeur de Marie

Vaulk, Patricia, 'The Society of the Daughters of the Heart of Mary in England'

\section{Diocesan Archives of Northampton}

A3.5 Collins MS

A3 Series Bishop Wareing, Convent Northampton

A6 Series Bishop Riddell's papers, women's congregations

F IV. 5 Convent Book

\section{Diocese of Nottingham Archives}

Box with rules and constitutions of various institutes

File cabinet contains files of various institutes

\section{FCJ: Faithful Companions of Jesus, Generalate Archives, Broadstairs, Kent}

Tomes 1-3 Profession Register of the Faithful Companions of Jesus

A656 Annual Relation 1874

A731 Annals 1883

A740 Annals 1884

A923 'Gumley House Annal Letter'

A1205 Annals 1895

A1209 Annals 1896

A1210 Annals 1896

A1842 Annals 1897

A1850 Annals 1898

A1854 Annals Book 11899

A1856 Annals Book 21899

Constitutions de la société des soeurs fidèles compagnes de jésus (Vannes: Imprimerie Galles, 1879)

d'Houët, Marie Madeleine Victoire de Bengy de Bonnault, The Early History of the Society of the Sisters Faithful Companions of Jesus as Related in the Memoirs of the Venerable Marie Madeleine Victoire de Bengy Viscountess de Bonnault d'Houët, translated by Patricia Grogan FCJ (Margate: Martell Press, 1981)

McCarren FCJ, Mary Campion, History of the Constitutions: Sisters, Faithful Companions of Jesus 1818-1985 (1993)

Rules for the Coadjutrix Sisters (Dublin: M.H. Gill \& Son, 1882)

Summary of the Constitutions (Dublin: M.H. Gill \&; Son, 1882)

\section{Leeds Diocesan Archives, Headingley, Leeds}

B/A John Briggs (1805-60) Correspondence

C/A Robert Cornthwaite (1837-90) Correspondence

File 20 Miscellaneous Religious Institutes 


\section{Little Company of Mary, Provincial Archives}

\section{RLR: Sisters of La Retraite, Regional Archives, Streatham, London}

Mother Imelda, 'Sevenoaks', 20 November 1951 or 1957, pink two-ring binder 'Sevenoaks', 1882

Applegate, Catherine, 'La Retraite: Origins and Growth', 1979

'Constitutions of the Society of the Sacred Heart of Jesus', 1884

\section{RSM Bermondsey: General Archives of the Institute of Our Lady of Mercy, Bermondsey}

Profession Register of the Sisters of Mercy

'Bermondsey Annals', 1839-1900

'Maxims of our Holy Foundress'

'Obituaries from Ursula O'Connor to Clare Arrowsmith'

200/3/3 'Rule and Constitutions of the Religious Sisters of Mercy of Our Blessed

Lady of Mercy', [1835?], inscription dated 1844

'Some Lives of the Sisters of Mercy Bermondsey', 1840-74

A Little Book of Practical Sayings, Advices and Prayers of Our Reverend Foundress Mother Mary Catharine [sic] McAuley, compiled by Mary Clare (Georgiana) Moore (London: Burns, Oates \& Co., 1868)

\section{RSM Dublin: Mercy International Archives, Dublin}

Manuscript photocopy, Annals, Sisters of Mercy Limerick, 1838-59

Manuscript photocopy, Annals, Sisters of Mercy Limerick, 1859-75

\section{RSM Handsworth: General Archives of the Union of the Sisters of Mercy of Great Britain, Handsworth}

Profession Register of the Sisters of Mercy

1/200/3/1 'Book of Customs', 1849, handwritten notes of 1849 meeting attended by Reverend Mother Juliana (Juliana Hardman) and Mother M. Aloysius (Mary

Elizabeth Jackson)

1/200/4/4 'Instruction for Novice Mistress', no date but copied between 1848 and 1884

1/200/9/1 'Handsworth Annals'

2/200/9/1 'Birmingham Annals'

4/300/2/3 'Documents Pertaining to St Anne's and St John's Convents'

5/200/9/1 'Coventry Annals'

7/200/9/2 'Chelsea Annals' 
[Bridgeman, M. Francis, RSM], Guide for the Religious Called Sisters of Mercy. Amplified by Quotations, Instructions, \&c. Fart I. \& II. (London: Robson and Son, 1866) , Abridgment of a Guide for the Religious Called Sisters of Mercy (London: Robson and Son, 1866)

Sisters of Mercy Derby 1849-1999: A Sesquiennial Celebration (1999)

\section{Salford Diocesan Archives, Burnley}

A1825-A1877 Laity Directories, 1825-1877

A1877-A1900 Mise Documents

Harvest (1897-current)

SCSP: Sisters of Charity of St Paul the Apostle Archives, Selly Park, Birmingham

Box 1 G. Dupuis, Personal Data, Early Letters

Box 4 Letters from Bishops

Box 26 'Registers of Postulants and Novices', 1847-1900

Box 80 Formation Notes

Rules and Constitutions of the Sisters of Charity of St Paul in England [1864]

\section{SHCJ: Society of the Holy Child Jesus Archives, Oxford}

Clothing Register (1846-1900)

Choir Postulants' Register (1892-1921)

'Necrologies'

'Memoir of the Rev. Mother Angelica Croft, Second Superior General of the Society of the Holy Child Jesus', 1913

[Connelly, Cornelia], Book of the Order of Studies in the Schools of the Holy Child Jesus (1863)

[Connelly, Cornelia], Manual for the Use of the Novices of the Holy Child Jesus (St Leonard's-on-Sea, 1869)

Box 54 R24 'Constitutions of the Society of the Holy Child Jesus', 1887, printer's proofs

Beatification and Canonization of the Servant of God Cornelia Connelly Foundress of the Society of the Holy Child Jesus: Documentation Presented by the Historical Commission:

Vol. 42 Training Colleges and School Affairs 1864-79

Vol. 49 Community Affairs Defections Part II

Vol. 51 Affairs of Government 1857-69 
Beatification and Canonization of the Servant of God Cornelia Connelly Foundress of the Society of the Holy Child Jesus: Writings of the Servant of God Cornelia Connelly:

Vol. VIII Letters of Members of the Society of the Holy Child Jesus

Vol. XIII Letters to Ecclesiastics Bishop Grant 1862-64

Vol. XVII Letters to Ecclesiastics Bishop Danell 1874-79

Forshaw, Helen, SHCJ, 'Choir and Lay: An Historical Perspective', in History Society of the Holy Child Jesus: Ministries Part II (2000), pp. 46-51

Mechtilde, S. Mary, SHCJ, Mother Mary Walburga SHCJ whose Years of Labor in the Society were its Seed Time in America (Rosemont, Pennsylvania, 1949)

Murphy, Anne, 'SHCJ and Ireland', in History Society of the Holy Child Jesus: Beginnings (1996), pp. 47-51

\section{SMG: Central Congregational Archive of the Poor Servants of the Mother of God, Brentford, Middlesex}

I/A Mother Magdalen's papers

I/B 'Annals'

I/C Papers relating to the foundation of the congregation, early houses and missions

I/D Personal accounts and narratives by Sisters

I/E Correspondence with clergy and religious

I/F Correspondence between Mother Magdalen and Lady Georgiana and Mr A.G.

Fullerton

I/P Letters from Mother Magdalen to Sisters from Paris

I/R Letters from Mother Magdalen to Sisters from Rome

Profession Register of the Poor Servants of the Mother of God

'An Eight Days' Retreat for the Poor Servants of the Mother of God given by Mother Foundress (M. Mary Magdalen of the Sacred Heart, S.M.G.)'

'Instructions of Mother Foundress on Our Holy Rule on Confession, etc. Taken from her Letters, and from Sisters' Notes'

'Mother Foundress' Letters to the Institute (1877-1900)', 1957

'Mother as We Knew Her', 1957

'Necrology Book I: 1872-1945', 1956

'Notes of Conferences given to Local Superiors by Mother Foundress, Mother Mary Magdalen of the Sacred Heart Poor Servant of the Mother of God'

I/C Rules \& Constitutions of the Poor Servants of the Mother of God and the Poor (1892)

I/C/1/4 'Constitutions SMG Vol 1st' and 'Constitutions SMG Vol 2nd'

\section{SND: Notre Dame Archives, British Province, Liverpool}

Registers of Professed Sisters for the British Province (1845-1900)

Mission Database 
Box 13 MPTC A Voice (1863-69)

BH2 Clapham CL.h/1 Transcribed Letters from Clapham to Namur 1848-1850'

BX BB/1 in BH1 'Blackburn Annals', 1860-1913

$\mathrm{BX} \mathrm{BB} / 2$ in BH1 F1 'Blackburn Community Matters'

BX BK/1 in BH1 'Birkdale Annals', 1878-1901

BX BS/1 in BH1 'Battersea Annals', 1892-1908

BX BS/4 in BH1 F1 'Battersea', 1869-1900

$\mathrm{BX}$ EV/1 in BH2 'Everton Annals'

$\mathrm{BX} P R V / 1$ - BX PRV/7 various documents

BX PRV/2 in BPND, box marked 'Province History 2: Notre Dame in England $1845-1850$

C3 'London Diary: Clapham', 1847-80

$\mathrm{NH}$ h/2 in BH3 'Northampton Annals', 1857-1900

$\mathrm{NH}$ h/3 in BH3 'Infant Jesus Documents'

PN.h/1 'English Translation of Letters to Namur'

Book of the Instructions of Blessed Mère Julie (1909)

Règles et Constitutions des Soeurs de Notre-dame (Namur, [1859])

SSJ: Sisters of St Joseph of Annecy Archives, Llantanam Abbey

Professed Sisters Register

Catholic Directory

\section{Newspapers and periodicals}

Catholic Times

The Harvest

Laity's Directory

The Tablet

The Times

\section{Other primary sources}

A.J.S., 'On the Secondary Education of Catholic Women', The Month (May 1894), 26-33.

Arbuthnot, Mrs, 'The Danger of Conventual Education and the Importance of Home Training', in Romanism and Ritualism in Great Britain and Ireland, A Report of the National Protestant Congress (Edinburgh: R.W. Hunter, 1895).

Avis, Whyte, The Catholic Girl in the World (London: Burns \& Oates, [1894]).

Bateson, Margaret, Professional Women upon their Professions (London: Horace Cox, 1895).

Bull, Paul, The Missioner's Handbook: A Guide for Missioners, Evangelists, and Parish Priests (London: Grant Richards, 1904).

The Canons and Decrees of the Council of Trent (London: Burns and Oates, 1848).

Casartelli, L.C., Catholic Missions (London: Catholic Truth Society, 1891). 
Chambers, Mary Catharine Elizabeth and Henry James Coleridge, The Life of Mary Ward (1585-1645), 2 vols (London: Burns and Oates, 1885).

Champneys, Basil, Memoirs and Correspondence of Coventry Patmore (London: George Bell and Sons, 1901).

Charlton, Barbara, The Recollections of a Northumbrian Lady, 1815-1866: Being the Memoirs of Barbara Charlton (nee Tasburgh) Wife of William Henry Charlton of Hesleyside Northumbrian ed. L.E.O. Charlton (London: Jonathan Cape, 1949).

Clarke, A.M., The Life of the Hon. Mrs. Edward Petre (Laura Stafford-Jerningham) in Religion Sister Mary of St. Francis, of the Congregation of the Sisters of Notre-Dame de Namur (London: Art and Book Company, 1899).

Connelly, Cornelia, God Alone: An Anthology of Spiritual Writings of Cornelia

Connelly, Foundress of the Society of the Holy Child Jesus (London: Burns \& Oates, 1959).

[Cusack, Margaret Anna], Five Years in a Protestant Sisterhood and Ten Years in a Catholic Convent, an Autobiography (London: Longmans, Green, 1869).

Cusack, M. Francis Clare, Life Inside the Church of Rome (London: Hodder and Stoughton, 1889).

, The Nun of Kenmare An Autobiography (London: Josiah Child, 1889).

Cusack, M.F., The Story of My Life (London: Hodder \& Stoughton, 1891).

De Paul, Vincent, The Conferences of St Vincent De Paul to the Daughters of Charity (London: Collins Liturgical Publications, 1979).

Deshon, George, Guide for Catholic Young Women, Especially for those Who Earn Their Own Living (New York: D. \& J. Sadler \& Co., 1863).

Devas, C.S., Studies of Family Life: A Contribution to Social Science (London: Burns and Oates, 1886).

Devine, Rev. Arthur, Convent Life; Or, The Duties of Sisters Dedicated in Religion to the Service of God, intended chiefly for Superiors and Confessors (London: The Passionists, 1889).

Ellis, Sarah Stickney, The Women of England, their Social Duties, and Domestic Habits (London: Fisher, Son \& Co., 1839).

, The Wives of England, Their Relative Duties, Domestic Influence, \& Social Obligations (London: Fisher, Son, \& Co., [1843]).

, The Daughters of England: Their Position in Society, Character and Responsibilities (London: Fisher, Son \& Co., 1845).

The Foundations of the Sisters of Notre Dame in England and Scotland from 1845 to 1895 (Liverpool: Philip, Son \& Nephew, 1895).

Gallwey, Father, SJ, Convent Life and England in the 19th Century: Two Sermons Preached in the Church of the Immaculate Conception, Farm Street, Mid-Lent, March 7th 1869, On Occasion of an Appeal on Behalf of the Little Sisters of the Poor (London: Burns, Oates \& Co., 1869).

, The Committee on Convents. The Nun's Choice: Newgate or Newdegate. A Letter to a Barrister (London: Burns, Oates, and Company, 1870).

Gordon-Gorman, W., Converts to Rome: Since the Tractarian Movement to May 1899 (London: Swan Sonnenschein \& Co., 1899).

Grant, Rev. Dr, Meditations of the Sisters of Mercy Before Renewal of Vows (London: Burns and Oates, 1874). 
Grey, Mrs William, Old Maids; A Lecture (London: William Ridgway, 1875).

[Harnett, Mary Vincent], The Life of Reverend Mother Catherine McAuley, Foundress of the Order of Mercy (Dublin: John Fowler, 1864).

Hetherington, Rev. Dr., 'Sisters of Mercy; or, Popery and Poverty', The Bulwark, 1 (1867).

Hubbard, Louisa M., 'Statistics of Women's Work', in Baroness [Angela] BurdettCoutts, ed., Woman's Work (London: Sampson Low, Marston \& Company, 1893), pp. 361-6.

Jameson, [Anna], Sisters of Charity Catholic and Protestant, Abroad and at Home (London: Longman, Brown, Green, \& Longmans, 1855).

Janes, Emily, 'On the Associated Work of Women in Religion and Philanthropy', in Baroness [Angela] Burdett-Coutts, ed., Woman's Mission (London: Sampson Low, Marston \& Company, 1893), pp. 131-48.

Kerr, Amabel, 'Mother Margaret Hallahan', The Catholic Magazine (August 1896), 76-89.

, Sister Chatelain or Forty Years' Work in Westminster (London: Catholic Truth Society, 1900).

[Lewis, Sarah], Woman's Mission (London: John W. Parker, 1839).

The Life of Madame de Bonnault d'Houët: Foundress of the Society of the Faithful Companions of Jesus (Dublin: M.H. Gill \& Son, 1885).

Liguori's Instructions on the Religious State, ed. Giovanni Battista Pagani (Derby: Richardson and Son, 1848).

Manning, Henry Edward, The Catholic Church and Modern Society (London: Cecil Brooks \& Co., 1880). , Lost Sheep Found: An Appeal for the Convents of the Good Shepherd (London: The Westminster Press, 1889).

Marshall, T.W.M., Christian Missions: Their Agents, Their Method, and Their Results (London: Burns and Lambert, 1862).

Martin, F. Abbé, Vie de Madame de Bonnault D'Houët Fondatrice de la Société des Fidèles Compagnes de Jésus (Paris: Librairie Saint-Joseph, 1863).

Murphy, John Nicholas, Terra Incognita: or, The convents of the United Kingdom (London, Longmans, Green \& Co., 1873).

O'Reilly, Rev. Bernard LD, The Mirror of True Womanhood: A Book of Instruction for Women in the World (Dublin: M.H. Gill \& Son, 1883).

Parliamentary Papers (1866), First Report of the Royal Commission Appointed to Inquire into the Working of the Elementary Education Acts, England and Wales, c.4863.

[Patmore, Coventry], Angel in the House: The Betrothal (London: John W. Parker and Son, 1854).

Records of the Foundation and Progress of the Congregation of the Sisters of the Most Holy Cross and Passion: 1851-1911 (Dublin, 1911).

Report on the Visitation of Females at their Own Homes in the City of Westminster (1854).

Rowe, J.B., Elementary Education and the Catholic Poor School Committee (London: Burns and Oates, 1876).

Ruskin, John, Sesame and Lilies. Two Lectures (London: Smith, Elder \& Co., 1865). 
Scott, R.E., 'Convent Education', The Month (June 1894), 197-216.

Seymour, Rev. M. Hobart, Convents or Nunneries. A Lecture in Reply to Cardinal Wiseman, delivered at the Assembly Rooms, Bath, on Monday, June 7, 1852 (Bath: R.E. Peach, 1852).

, On Convents. The Speech of the Rev. M. Hobart Seymour, at the Meeting of the Protestant Alliance, held in St James Hall, Piccadilly, On February 24th, 1865 (London: Protestant Alliance, 1865).

'The "Sisters of Peace" in the Dioceses of Nottingham', The Tablet (12 January 1884), 72.

Spurrell, James, Miss Sellon and the 'Sisters of Mercy. 'An Exposure of the Constitution, Rules, Religious Views, and Practical Working of their Society; Obtained through a 'Sister,' who has recently Seceded (London: Thomas Hatchard, 1852).

Stanislaus, R.P., Notice sur la vie, les vertues et les oeuvres de la Servante de Dieu Marie Madeleine Victoire de Bengy, Viscountesse de Bonnault d'Houët (Paris, France: J. Mersch, 1895).

The Synods in English: Being the Text of the Four Synods of Westminster, ed. Robert E. Guy OSB (Stratford-on-Avon: St Gregory's Press, 1886).

Thomson, H. Byerley, The Choice of a Profession: A Concise Account and Comparative Review of the English Professions (London: Chapman and Hall, 1857).

Thurston, Herbert, 'Two Modern Dominicanesses', The Month (October 1895), 183-204.

Ullathorne, Bishop, A Plea for the Rights and Liberties of Religious Women, with reference to the Bill proposed by Mr. Lacy (London: Thomas Richardson and Son, 1851).

, A Letter addressed to Lord Edward Howard, on the Proposed Committee of Enquiry into Religious Communities (London: Thomas Richardson and Son, 1854).

, Three Lectures on the Conventual Life (London: Burns, Oates \& Co., 1868).

Walker, Alexander, Woman Physiologically Considered, as to Mind, Morals, Marriage, Matrimonial Slavery, Infidelity and Divorce (London: A.H. Bailey \& Co., 1839).

Ward, Mary, Till God Will: Mary Ward through her Writings, ed. M. Emmanuel Orchard IBVM (London: Darton, Longman \& Todd, 1985).

'What of our Convent Schools?' The Month (April 1894), 517-26.

Wiseman, Nicholas, 'Froud's Remains', Dublin Review, 6 (May 1839), 416-35.

Woman: As She Is, and As She Should be (London: James Cochrane and Co., 1835).

\section{Unpublished theses}

Adams, Pauline A., 'Converts to the Roman Catholic Church in England, circa. 1830-1870' (doctoral thesis, Somerville College, Oxford, 1977).

Barnhiser, Judith Anne, OSU, 'A Study of the Authority Structures of Three Nineteenth-Century Apostolic Communities of Religious Women in the United States' (doctoral thesis, Catholic University of America, 1975). 
Barrus, Katherine DeMartini, "'Putting Her Hand to the Plough": Nuns and Sisters in Nineteenth-Century England' (doctoral thesis, University of Albany, State University of New York, 1999).

Edmunds, May P., 'But the Greatest of These is Chastity . . .' (doctoral thesis, Australian National University, 1986).

Jarrell, Lynn, OSU, 'The Development of Legal Structures for Women Religious between 1500 and 1900: A Study of Selected Institutes of Religious Life for Women' (doctoral thesis, Catholic University of America, 1984).

Kitching, Jack, 'Roman Catholic Education from 1700-1870: A Study of Roman Catholic Educational Endeavour from the Early Eighteenth Century to the Elementary Education Act of 1870' (doctoral thesis, University of Leeds, 1966).

Lannon, David, 'Bishop Turner and Educational Provision within the Salford Diocesan Area 1840-1870' (master's thesis, University of Hull, 1994).

Lowden, Kim, 'Spirited Sisters: Anglican and Catholic Contribution to Women's Teacher Training in the 19th Century' (doctoral thesis, Liverpool Hope University, 2000).

McAdam, Gloria, “"My Dear Sister . ..”: An Analysis of 19th Century Documents Concerning the Founding of a Women's Religious Congregation' (doctoral thesis, University of Bradford, 1994).

Mangion, Carmen M., 'Centre of a Maelstrom: Anglican Sisterhoods in Victorian England' (master's thesis, Birkbeck College, University of London, 2000). , 'Contested Identities: Active Women Religious in Nineteenth-Century England and Wales' (doctoral thesis, Birkbeck College, University of London, 2005).

Marmion, John P., 'Cornelia Connelly's Work in Education, 1848-1879' (doctoral thesis, University of Manchester, 1984).

Stone, Hope Campbell Barton, 'Constraints on the Mother Foundresses: Contrasts in Anglican and Roman Catholic Religious Headship in Victorian England' (doctoral thesis, University of Leeds, 1993).

\section{Secondary sources}

Acker, Sandra, 'Caring as Work for Women Educators', in Elizabeth Smyth, Sandra Acker, Sandra Bourne and Alison Prentice, eds, Challenging Professions: Historical and Contemporary Perspectives on Women's Professional Work (Toronto: University of Toronto Press, 1999), pp. 277-95.

Allen, Sheila, 'Identity: Feminist Perspectives on "Race", Ethnicity and Nationality', in Nickie Charles and Helen Hintjens, eds, Gender, Ethnicity and Political Ideologies, (London: Routledge, 1998), pp. 46-64.

Altholtz, J.L., 'The Political Behaviour of English Catholics, 1850-67', Journal of British Studies, 4 (1964), 89-103.

Anderson, Benedict, Imagined Communities: Reflections on the Origin and Spread of Nationalism (London: Verso, 1991).

Anson, Peter E, The Religious Orders and Congregations of Great Britain and Ireland (Worcester: Stanbrook Abbey, 1949).

Armstrong, W.A., 'The Use of Information about Occupation', in E.A. Wrigley, ed., Nineteenth-Century Society: Essays in the use of Quantitative Methods for the 
Study of Social Data (Cambridge: Cambridge University Press, 1972), pp. 191310.

Arnstein, Walter L., Protestant versus Catholic in Mid-Victorian England: Mr. Newdegate and the Nuns (London: University of Missouri Press, 1982).

Atkin, Nicholas, 'The Politics of Legality: The Religious Orders in France, 1901-45', in Frank Tallett and Nicholas Atkin, eds, Religion, Society and Politics in France since 1789 (London: The Hambledon Press, 1991), pp. 149-66.

Attwater, Donald, The Catholic Church in Modern Wales: A Record of the Past History (London: Burns Oates \& Washbourne, 1935).

Augustine, P. Chas., OSB, DD, A Commentary on the New Code of Canon Law, 8 vols (London: B. Herder Book Co., 1918).

Bates, M. Rita, Living his Theme Song: Virtues of Mother M. Evangelista Gaffney (Paterson, New Jersey: St Anthony Guild Press, 1953).

Battersby, W.J., 'The Educational Work of the Religious Orders of Women: 18501950', in George Andrew Beck, ed., The English Catholics, 1850-1950 (London: Burns Oates, 1950), pp. 337-64.

Bellenger, Dom Aidan, 'France and England: The English Female Religious from Reformation to World War', in Frank Tallett and Nicholas Atkin, eds, Catholicism in Britain and France since 1789 (London: The Hambledon Press, 1996), pp. 3-11.

Bennett, John, 'The Care of the Poor', in George Andrew Beck, ed., The English Catholics, 1850-1950 (London: Burns Oates, 1950), pp. 559-84.

Blake, Sister Ursula Blake, and Sister Annette Dawson, Positio: Information for the Canonization Process of the Servant of God Cornelia Connelly (née Peacock) 1809-1879, 3 vols (Rome: Sacred Congregation for the Causes of Saints, 1983).

Blott, K., A Hundred Years: A History of the ECJ.'s in Middlesbrough 1872-1972 with Particular Reference to the Growth of St Mary's Convent School (Middlesbrough: H. \& F. Stokeld Printers, 1972).

Bossy, John, The English Catholic Community, 1570-1850 (London: Darton, Longman \& Todd, 1975).

, 'English Catholics after 1688', in Ole Peter Grell, Jonathan I. Israel and Nicholas Tyacke, eds, From Persecution to Toleration: The Glorious Revolution and Religion in England (Oxford: Clarendon Press, 1991), pp. 369-88.

Bowden, Caroline, 'Approaching Prosopographical Studies in the Early Modern Period: The Case of the English Convents', paper presented at conference entitled 'Consecrated Women: Towards the History of Women Religious of Britain and Ireland', Birkbeck College, London, 2003.

, 'Community Space and Cultural Transmission: Formation and Schooling in English Enclosed Convents in the Seventeenth Century', History of Education, 34 (2005), 365-86.

Branca, Patricia, Silent Sisterhood: Middle-Class Women in the Victorian Home (London: Croom-Helm, 1975).

Bryant, Margaret, The Unexpected Revolution: A Study in the History of the Education of Women and Girls in the Nineteenth Century (London: University of London Institute of Education, 1979).

Burley, Stephanie, 'An Overview of the Historiography of Women Religious in Australia', journal of the Australian Catholic Historical Society, 26 (2005), 4360 . 
Burstyn, Joan N., Victorian Education and the Ideal of Womanhood (London: Croom Helm, 1980).

Callahan, Francis, The Centralization of Government in Pontifical Institutes of Women with Simple Vows (Rome: Gregorian University, 1948).

Casteras, Susan P., 'Virgin Vows: The Early Victorian Artists' Portrayal of Nuns and Novices', Victorian Studies, 24 (winter 1981), 157-84.

Chadwick, Owen, The Spirit of the Oxford Movement (Cambridge: Cambridge University Press, 1990).

Charles, Nickie, 'Feminist Practices: Identity, Difference, Power', in Nickie Charles and Felicia Hughes-Freeland, eds, Practising Feminism: Identity, Difference, Power (London: Routledge, 1996), pp. 1-37.

Clear, Caitriona, Nuns in Nineteenth-Century Ireland (Dublin: Gill and Macmillan, 1987).

, 'Walls within Walls: Nuns in Nineteenth-Century Ireland', in Chris Curtin, ed., Gender in Irish Society (Galway: Galway University Press, 1987), pp. 134-51.

, 'The Limits of Female Autonomy: Nuns in Nineteenth-Century Ireland', in Maria Luddy and Cliona Murphy, eds, Women Surviving: Studies in Irish Women's History in the 19th and 20th Centuries (Dublin: Poolpeg, 1990), pp. $15-50$.

Coburn, Carol K. and Martha Smith, Spirited Lives: How Nuns Shaped Catholic Culture and American Life, 1836-1920 (Chapel Hill and London: The University of North Carolina Press, 1999).

, 'An Overview of the Historiography of Women Religious: A Twenty-FiveYear Retrospective', U.S. Catholic Historian, 22 (winter 2004), 1-26.

Copelman, Dina M., London's Women Teachers: Gender, Class and Feminism 18701930 (London: Routledge, 1996).

Corfleld, Penelope J., Power and the Professions 1700-1850 (London: Routledge, 1995).

Cott, Nancy R, The Bonds of Womanhood: 'Woman's Sphere' in New England, 1780-1835 (London: Yale University Press, 1977).

Cox, Jeffrey, 'Audience and Exclusion at the Margins of Imperial History', Women's History Review, 3 (1994), 501-14.

Crawford, Patricia, Women and Religion in England 1500-1720 (London: Routledge, 1993).

, 'Women, Religion and Social Action in England, 1500-1800', Australian Feminist Studies, 13 (1998), 269-80.

Cruise, Edward, 'Development of Religious Orders' in George Andrew Beck, ed., The English Catholics, 1850-1950 (London: Burns Oates, 1950), pp. 442-74.

Cullen, Mary and Maria Luddy, Women, Power and Consciousness in 19th Century Ireland (Dublin: Attic Press, 1995).

Cunningham, Hugh and Joanna Innes, eds, Charity, Philanthropy and Reform: from the 1690s to 1850 (Basingstoke: St Martin's Press, 1998).

Curtis, Sarah A., 'Lay Habits: Religious Teachers and the Secularization Crisis of 1901-1904', French History, 9 (1995), 478-98.

, Educating the Faithful: Religion, Schooling, and Society in NineteenthCentury France (Dekalb, Illinois: Northern Illinois Press, 2000). 
Danylewycz, Marta, Taking the Veil: An Alternative to Marriage, Motherhood, and Spinsterhood in Quebec, 1840-1920 (Toronto, Canada: McClelland and Stewart, 1987).

Daunton, Martin, Charity, Self-Interest and Welfare in the English Past (London: UCL Press, 1996).

Davidoff, Leonore, 'Where the Stranger Begins: The Question of Siblings in Historical Analysis', in Leonore Davidoff, ed., Worlds Between: Historical Perspectives on Gender and Class (Cambridge: Polity Press, 1995), pp. 206-21.

Davidoff, Leonore, and Catherine Hall, Family Fortunes: Men and Women of the English Middle Class, 1780-1850 (London: Hutchinson, 1987).

Davidoff, Leonore, Megan Doolittle, Janet Fink and Katherine Holden, The Family Story: Blood, Contract and Intimacy, 1830-1960 (London: Longman, 1999).

Decree on the Adaptation and Renewal of Religious Life, Perfectae caritatis (28 October 1965), www.vatican.va/archive/hist_councils/ii_vatican_council/ [accessed 29 August 2006].

Devas, F.C., SJ, Mother Mary Magdalen of the Sacred Heart (Fanny Margaret Taylor): Foundress of the Poor Servants of the Mother of God 1832-1900 (London: Burns, Oates \& Washbourne, 1927).

Dewitt, Susan, CSJP, A Great Love of Peace (Bellevue, Washington: CSJP, 2000).

Digby, Anne and Peter Searby, Children, School and Society in Nineteenth-Century England (London: The Macmillan Press, 1981).

Diner, Hasia, Erin's Daughters in America: Irish Immigrant Women in the Nineteenth Century (Baltimore, Maryland, USA: The John Hopkins University Press, 1983).

Dougherty, Patrick, Mother Mary Potter: Foundress of the Little Company of Mary (1847-1913) (London: Sands \& Co., Ltd., 1961).

Doyle, Peter, 'The Education and Training of Catholic Priests in Nineteenth-Century England', Journal of Ecclesiastical History, 35 (1984), 208-19.

, 'Family and Marriage', in V. Alan McClelland and Michael Hodgetts, eds, From Without the Flaminian Gate: 150 Years of Roman Catholicism in England and Wales 1850-2000 (London: Darton Longman \& Todd, 1999), pp. 192-216.

Dyhouse, Carol, 'Mothers and Daughters in the Middle-Class Home, c. 1870-1914' in Jane Lewis, ed., Labour \& Love: Women's Experience of Home and Family 1850-1940 (Oxford: Basil Blackwell, 1986), pp. 27-48.

Ebaugh, Helen Rose, 'Patriarchal Bargains and Latent Avenues of Social Mobility: Nuns in the Roman Catholic Church', Gender and Society (September 1993), 400-14.

Edwards, Elizabeth, 'Educational Institutions or Extended Families? The Reconstruction of Gender in Women's Colleges in the Late Nineteenth and Early Twentieth Centuries', Gender and Education, 2 (1990), 17-35.

Engelhardt, Carol Marie, 'The Paradigmatic Angel in the House: The Virgin Mary and Victorian Anglicans', in Anne Hogan and Andrew Bradstock, eds, Women of Faith in Victorian Culture: Reassessing the Angel in the House (London: Macmillan Press Ltd., 1998), pp. 159-71.

Faderman, Lilian, Surpassing the Love of Men: Romantic Friendship and Love between Women from the Renaissance to the Present (London: The Women's Press, 1981). 
Fahey, Tony, 'Nuns in the Catholic Church in Ireland in the Nineteenth Century', in Mary Cullen, ed., Girls Don't Do Honours: Irish Women in Education in the $19^{\text {th }}$ and 20th Centuries (Dublin: Women's Education Bureau, 1987), pp. 7-30.

Fielding, Stephen, Class and Ethnicity: Irish Catholics in England, 1880-1939 (Buckingham: Open University Press, 1993).

Fiorenza, Elisabeth Schussler, In Memory of Her: A Feminist Theological Reconstruction of Christ Origins (London: SCM Press, 1994).

Fitzgerald-Lombard, Charles, English and Welsh Priests 1801-1914: A Working List (Bath, England: Downside Abbey, 1993).

Fitzpatrick, David, 'A Curious Middle Place: The Irish in Britain, 1871-1921', in Roger Swift and Sheridan Gilley, eds, The Irish in Britain 1815-1939 (London: Pinter Publishers, 1989), pp. 10-59.

Flaxman, Radegunde, A Woman Styled Bold: The Life of Cornelia Connelly, 18091879 (London: Darton Longman \& Todd, 1991).

Gibson, Ralph, The Christianisation of the Countryside in Western Europe in the Nineteenth century', in J.-P. Massaut and M.-E. Henneau, eds, La christianisation de Campagnes (Rome: Institut Historique Belge de Rome, 1996), pp. 485-509.

, 'Female Religious Orders in Nineteenth-Century France', in Frank Tallett and Nicholas Atkin, eds, Catholicism in Britain and France since 1789 (London: The Hambledon Press, 1996), pp. 105-13.

Giddens, Anthony, Modernity and Self-Identity: Self and Society in the Late Modern Age (Cambridge: Polity Press, 1991).

Gill, Sean, Women and the Church of England from the Eighteenth-Century to the Present (London: Society for Promoting Christian Knowledge, 1994).

, 'Heroines of Missionary Adventure: The Portrayal of Victorian Women Missionaries in Popular Fiction and Biography', in A. Hogan and A. Bradstock, eds, Women of Faith in Victorian Culture: Reassessing the Angel in the House (Dublin: Macmillan Press Ltd, 1998), pp. 172-85.

Gilley, Sheridan, 'The Roman Catholic Mission to the Irish in London', Recusant History, 10 (1969-70), 123-45.

, 'Protestant London, No-Popery and the Irish Poor: 1830-60 (Part I)', Recusant History, 10 (1969-70), 210-30.

, 'Protestant London, No-Popery and the Irish Poor: 1850-60 (Part II)', Recusant History, 11 (1971-72), 21-46.

, 'English Catholic Charity and the Irish Poor in London: Part I, 1700-1840', Recusant History, 11 (1971-72), 179-95.

, 'English Catholic Charity and the Irish Poor in London: Part II, 18401870', Recusant History, 11 (1971-72), 253-69.

, 'Papists, Protestants and the Irish in London, 1835-70', in G.J. Cuming and

D. Baker, eds, Popular Belief and Practice: Papers Read at the Ninth Summer Meeting and the Tenth Winter Meeting of the Ecclesiastical History Society (Cambridge: University Press, 1972), pp. 259-76.

, 'Roman Catholicism and the Irish in England', Immigrants \& Minorities [Great Britain], 18 (1999), 147-67.

, 'The Years of Equipose, 1892-1943', in V. Alan McClelland and Michael Hodgetts, eds, From without the Flaminian Gate: 150 Years of Roman Catholicism in England and Wales 1850-2000 (London: Darton Longman \& Todd, 1999), pp. 21-61. 
Gittins, Diana, 'Marital Status, Work and Kinship, 1850-1930', in Jane Lewis, ed., Labour and Love: Women's Experience of Home and Family 1850-1940 (Oxford: Basil Blackwell, 1986), pp. 249-67.

, The Family in Question: Changing Households and Familiar Ideologies (London: Macmillan, 1993).

Gleadle, Katherine, The Early Feminists: Radical Unitarians and the Emergence of the Women's Rights Movement, 1831-1851 (London: Routledge, 1995).

Goddijn, H.P.M., 'The Sociology of Religious Orders and Congregations', Social Compass, 7 (1960), 431-47.

Gomersall, Meg, Working-Class Girls in Nineteenth-Century England (London: Macmillan Press, 1997).

[Gompertz, Mary Catherine], Cornelia Connelly, 1809-1879: Foundress of the Society of the Holy Child Jesus (London: Longmans, Green and Co., 1950).

Gordon, Eleanor and Gweneth Nair, The Myth of the Victorian Patriarchal Family', The History of the Family, 7 (2002), 125-38.

Gorham, Deborah, The Victorian Girl and the Feminine Ideal (London: Croom Helm, 1982).

Gove, Jennifer and Stuart Watt, 'Identity and Gender', in Kath Woodward, ed., Questioning Identity: Gender, Class, Nation (London: Open University Press, 2000), pp. 43-78.

Gwynn, Denis, 'Growth of the Catholic Community', in George Andrew Beck, ed., The English Catholics, 1850-1950 (London: Burns Oates, 1950), pp. 410-42.

Gwynn, M.M. Xavier, SHCJ, From Hunting Field to Cloister (Dublin: Clonmore and Reynolds, 1946).

Hall, Catherine, 'The Early Formation of Victorian Domestic Ideology', in Sandra Burman, ed., Fit Work for Women (London: Croom Helm, 1979), pp. 15-32.

Hamer, Edna, Elizabeth Prout, 1820-1864: A Religious Life for Industrial England (Bath, England: Downside Abbey, 1994).

Heimann, Mary, Catholic Devotion in Victorian England (Oxford: Clarendon Press, 1995).

, 'Devotional Stereotypes in English Catholicism, 1850-1914', in Frank Tallett and Nicholas Atkin, eds, Catholicism in Britain and France since 1789 (London: The Hambledon Press, 1995), pp. 13-25.

Hexter, J.H., 'The Protestant Revival and the Catholic Question in England, 17781829', The Journal of Modern History, 8 (1936), 297-319.

Hickey, Daniel, Hospitals in Ancien Regime France: Rationalization, Resistance, Renewal 1530-1789 (Montreal: McGill-Queen's University Press, 1997).

Hickman, Mary J., Religion, Class and Identity: The State, the Catholic Church and the Education of the Irish in Britain (Aldershot, England: Avebury, 1995).

, 'Incorporating and Denationalizing the Irish in England: The Role of the Catholic Church', in Frank O'Sullivan, ed., The Irish World Wide History, Heritage, Identity (London: Leicester University Press, 1996), pp. 196-216.

Hilton, Mary and Pam Hirsch, eds, Practical Visionaries: Women, Education and Social Progress, 1790-1930 (London: Longman, 2000).

Hogan, Anne, 'Angel or Eve?: Victorian Catholicism and the Angel in the House', in Anne Hogan and Andrew Bradstock, eds, Women of Faith in Victorian Culture: Reassessing the Angel in the House (London: Macmillan Press Ltd, 1998), pp. 91-100. 
Hogan, Edmund M., The Irish Missionary Movement: A Historical Survey 1830-1980 (Dublin: Gill and Macmillan, 1990).

Hohn, Rev. H[ermann], Vocations: Conditions for Admission, etc., into the Convents, Congregations, Societies, Religious Institutes etc. According to Authentical Information and the Latest Regulations (London: R \& T Washbourne, 1912).

Holcombe, Lee, Victorian Ladies at Work (London: Archon Books, 1973).

Holmes, Geoffrey, Augustan England: Profession, State and Society, 1680-1730 (London: George Allen tte, Un win, 1982).

Holmes, J. Derek, More Roman than Rome: English Catholicism in the Nineteenth Century (London: Burns and Oates, 1978).

Holton, Sandra Stanley, Alison Mackinnon, and Margaret Allen, 'Introduction', Women's History Review, 7/2 (1998), 163-9.

Hoy, Suellen, 'The Journey Out: The Recruitment and Emigration of Irish Religious Women to the United States, 1812-1914', Journal of Women's History, 6/7 (1995), 64-98.

Hoy, Suellen and Margaret MacCurtain, From Dublin to New Orleans: The Journey of Nora and Alice (Dublin: Attic Press, 1994).

Hudson, George V., Mother Geneviève Dupuis, Foundress of the English Congregation of the Sisters of Charity of St Paul the Apostle 1813-1903 (London: Sheed \& Ward, 1929).

Hufton, Olwen, Whatever Happened to the History of the Nun? (Royal Holloway, University of London: Royal Holloway, 1999).

Hufton, Olwen and Frank Tallett, 'Communities of Women, the Religious Life and Public Service in Eighteenth-Century France', in Marilyn J. Boxer and Jean H. Quataert, eds, Connecting Spheres: Women in the Western World, 1500 to the Present (New York: Oxford University Press, 1984), pp. 75-85.

Hughes, Trystan O., Winds of Change: The Roman Catholic Church and Society in Wales 1916-62 (Cardiff: University of Wales Press, 1999).

Jones, Colin, The Charitable Imperative: Hospitals and Nursing in Ancient Regime and Revolutionary France (London: Routledge, 1989).

, 'Sisters of Charity and the Ailing Poor', Social History of Medicine, 2 (1989), 339-48.

Kanya-Forstner, Martha, 'Defining Womanhood: Irish Women and the Catholic Church in Victorian Liverpool', in Donald M. MacRaild, ed., The Great Famine and Beyond: Irish Migrants in Britain in the Nineteenth and Twentieth Centuries (Dublin: Irish Academic Press, 2000), pp. 168-88.

Keats-Rohan, KSB, 'Prosopography and Computing: A Marriage Made in Heaven?', History and Computing, 12 (2000), 1-13.

Kent, John, Holding the Fort: Studies in Victorian Revivalism (London: Epworth Press, 1978).

Kerr, Cecil, Memoir of a Sister of Charity: Lady Etheldreda Fitzalan Howard (London: Burns Oates \& Washbourne, 1928).

Kerr, Cecil, Edith Fielding Sister of Charity (London: Sands \& Company, 1933).

Kidd, Alan J., 'Philanthropy and the "Social History Paradigm"', Social History, 21 (1996), 180-92.

Kirkus, Sr M. Gregory, IBVM, The Institute of the Blessed Virgin Mary: An Historical Sketch of the Institute in England (1993).

Kirkus, Sr M. Gregory, An LB. V.M. Biographical Dictionary of the English Members and Major Benefactors (London: Catholic Record Society, 2001). 
Klaus, Robert J., The Pope, the Protestants, and the Irish: Papal Aggression and Anti-Catholicism in Mid-Nineteenth Century England (London: Garland Publishing, 1987).

Lancaster, Judith, Cornelia Connelly and her Interpreters (Oxford: The Way, 2004).

Langland, Elizabeth, Nobody's Angels: Middle-Class Women and Domestic Ideology in Victorian Culture (London: Cornell University Press, 1995).

Langlois, Claude, 'Les effectifs des congrégations féminines au XIXe siècle: de l'enquête statistique à l'histoire quantitative', Revue d'Histoire de l'Eglise de France, 60(1974), 39-64.

Langlois, Claude, Le catholicisme au féminin: les congrégations françaises à supérieure générale au XIXe siècle, histoire (Paris: Les Editions du Cerf, 1984).

Lascelles, E.C.P., 'Charity', in G. M. Young, ed., Early Victorian England, 18301865 (London, 1934), II, pp. 315-48.

Laslett, Peter, 'England: The Household over Three Centuries', in Peter Laslett and Richard Wall, eds, Household and Family in Past Time: Comparative Studies in the Size and Structure of the Domestic Group over the Last Three Centuries in England, France, Serbia, japan and Colonial North America, with Further Materials from Western Europe (Cambridge: Cambridge University Press, 1972), pp. 125-58.

Lee, Joseph J., 'Women and the Church since the Famine', in Margaret MacCurtain and Donncha O Corrain, eds, Women in Irish Society: The Historical Dimension (Dublin: Arlen House, 1978), pp. 37-45.

Lees, Lynn Hollen, Exiles of Erin: Irish Migrants in Victorian London (Manchester: Manchester University Press, 1979).

Lewis, Jane, 'Introduction: Reconstructing Women's Experience of Home and Family', in Jane Lewis, ed., Labour \& Love: Women's Experience of Home and Family 1850-1940 (Oxford: Basil Blackwell, 1986), pp. 1-24.

, 'Women and Late-Nineteenth-Century Social Work', in Carol Smart, ed., Regulating Womanhood: Historical essays on Marriage, Motherhood and Sexuality (London: Routledge, 1992), pp. 78-99.

Leys, M.D.R., Catholics in England 1559-1829: A Social History (London: Longmans, 1961).

Linscott, Mary, Quiet Revolution: The Educational Experience of Blessed Julie Billiart and the Sisters of Notre Dame de Namur (Glasgow: Burns, 1966).

, 'The Experience of Women Religious', in Noel Timms and Kenneth Wilson, eds, Governance and Authority in the Roman Catholic Church: Beginning a Conversation (London: SPCK, 2000), pp. 70-90.

Lonergan, Margaret, 'The Archives of the Anglo-Scottish Province of the Little Sisters of the Assumption', Catholic Archives Journal, 11 (1991) 17-23.

Luddy, Maria, 'Women and Charitable Organisations in Nineteenth Century Ireland', Women's Studies International Forum, 11 (1988), 301-5.

, 'An Agenda for Women's History in Ireland: 1800-1900', Irish Historical Studies, 28 (1992), 19-37.

, 'An Outcast Community: The "Wrens" of the Curragh', Women's History

Review, 1 (1992), 341-84.

, Women and Philanthropy in Nineteenth-Century Ireland (Cambridge:

Cambridge University Press, 1995).

, “Abandoned Women and Bad Characters': Prostitution in Nineteenth-

Century Ireland', Women's History Review, 6 (1997), 485-505. 
, 'Religion, Philanthropy and the State in Eighteenth- and Early NineteenthCentury Ireland', in Hugh Cunningham and Joanna Innes, eds, Charity, Philanthropy and Reform from the 1690s to 1850 (London: Macmillan Press Ltd, 1998), pp. 148-67.

McAdam, Gloria, 'Willing Women and the Rise of Convents in Nineteenth-Century England', Women's History Review, 8 (1999), 411-41.

McCarren, Mary Campion, FCJ, Faithful Companion of Jesus: Venerable Marie Madeleine Victoire de Bengy, Viscountess de Bonnault d'Houët 1781-1858, Foundress of the Society of Sisters Faithful Companions of Jesus (London: Catholic Truth Society, 1981).

McCarthy, Caritas, The Spirituality of Cornelia Connelly: In God, For God, With God (Lewiston, New York, USA: Edwin Mellen Press, 1986).

McClelland, Maria G., 'In Search of the Hull Mercy Nuns: An Archival Travelogue', Catholic Archives Journal, 16 (1996), 37-53.

, The Sisters of Mercy, Popular Politics and the Growth of the Roman Catholic Community in Hull, 1855-1930 (Lewiston, NY: Queenston, Lampeter: The Edwin Mellen Press, 2000).

McClelland, V. Alan, 'From Without the Flaminian Gate', in V. Alan McClelland and Michael Hodgetts, eds, From without the Flaminian Gate: 150 Years of Roman Catholicism in England and Wales (London: Darton Longman \&; Todd, 1999), pp. 1-20.

MacCurtain, Margaret, Towards an Appraisal of the Religious Image of Women', The Crane Bag, 4 (1980), 26-30.

, 'Late in the Field: Catholic Sisters in Twentieth-Century Ireland and the New Religious History', in Mary O'Dowd and Sabine Wichert, eds, Chattel, Servant or Citizen. Women's Status in Church, State and Society (Belfast: The Institute of Irish Studies, 1995), pp. 34-44.

, 'Godly Burdens: The Catholic Sisterhoods in Twentieth Century Ireland', in Anthony Bradley and Maryann Gialanella Valiulis, eds, Gender and Sexuality in Modern Ireland (Amherst: University of Massachusetts Press, 1997), pp. 245-56.

, 'Catholic Sisterhoods in 20th-century Ireland', Religious Life Review, 39 (2000), 19-31.

McDermott, M. Rosarii, The Undivided Heart: The Life of Mother Evangelista First Mother General of the Sisters of St Joseph of Newark (Newark, New Jersey: St Anthony Guild Press, 1961).

MacGinley, M.R., PBVM, A Dynamic of Hope: Institutes of Women Religious in Australia (Darlinghurst, New South Wales: Crossing Press, 2002).

McGrath, Madeleine Sophie, These women? Women Religious in the History of Australia: The Sisters of Mercy Parramatta 1888-1988 (Kensington, New South Wales: New South Wales University Press, 1992).

McNamara, Jo Ann Kay, Sisters in Arms: Catholic Nuns through Two Millennia (London: Harvard University Press, 1996).

Magray, Mary Peckham, The Transforming Power of the Nuns: Women, Religion, and Cultural Change in Ireland, 1750-1900 (Oxford: Oxford University Press, 1998).

Makowski, Elizabeth M., Canon Law and Cloistered Women: Periculoso and its Commentators, 1298-1545 (Washington, DC: Catholic University of America Press, 1997). 
Malmgreen, Gail, 'Introduction', in Religion in the Lives of English Women, 17601930, ed. by Gail Malmgreen (London \& Sydney: Croom Helm, 1986), pp. 110.

, 'Domestic Discords: Women and the Family in East Cheshire Methodism, 1750-1830', in Jim Okelkevich, Lyndal Roper and Raphael Samuel, eds, Disciplines of Faith: Studies in Religion, Politics and Patriarchy (London: Routledge, 1987), pp. 55-70.

Mangion, Carmen M., “Good Teacher" or "Good Religious"?: The Professional Identity of Catholic Women Religious in nineteenth-century England and Wales', Women's History Review, 14 (2005), pp. 223-42.

, 'Laying "good strong foundations": The Power of the Symbolic in the Formation of a Religious Sister', Women's History Review, 16 (2007), 403-15.

Mannard, Joseph G, “"A Kind of Noah's Ark": Vocations of Women Religious in the Archdiocese of Baltimore, 1790-1860', paper presented at conference entitled 'Triennial Meeting of the Conference for the History of Women Religious Through Multiple Lenses: Interdisciplinary Perspectives on the History of Women Religious', Loyola University, Lake Shore Campus, Chicago, Illinois, 1998.

Marks, Lynne, 'The "Hallelujah Lasses": Working-Class Women in the Salvation Army in English Canada, 1882-92', in Franca Iacovetta and Mariana Valverde, eds, Gender Conflicts: New Essays in Women's History (Toronto: University of Toronto Press, 1992), pp. 67-117.

Marmion, John P., 'The Beginnings of the Catholic Poor Schools in England', Recusant History, 17 (1984-85), 67-83.

Mary Elizabeth Towneley (in religion Sister Marie des Saints Anges): Provincial of the English Province of The Sisters of Notre Dame ofNamur: A Memoir (London: Burns Oates and Washbourne, 1924).

Matchinske, Megan, Writing, Gender and State in Early Modern England: Identity Formation and the Female Subject (Cambridge: Cambridge University Press, 1998).

Mathew, David, 'Old Catholics and Converts', in George Andrew Beck, ed., The English Catholics, 1850-1950 (London: Burns Oates, 1950), pp. 223-42.

Melnyk, Julie, ed., Women's Theology in Nineteenth-Century Britain: Transfiguring the Faith of their Fathers (London: Garland Publishing, 1998).

Milbank, Alison, 'Josephine Butler: Christianity, Feminism and Social Action', in Jim Obelkevich, Lynda Roper and Raphael Samuel, eds, Disciplines of Faith: Studies in Religion, Politics and Patriarchy (London: Routledge, 1987), pp. 154-64.

Mills, D.R. and K. Schurer, 'Employment and Occupations', in Dennis Mills and Kevin Schurer, eds, Local Communities in the Victorian Census Enumerators' Books (Oxford: Leopard's Head Press Limited, 1996), pp. 136-60.

Mills, Hazel, 'Negotiating the Divide: Women, Philanthropy and the "Public Sphere" in Nineteenth-Century France', in Frank Tallett and Nicholas Atkin, eds, Religion, Society and Politics in France since 1789 (London: The Hambledon Press, 1991), pp. 29-54.

, "Saintes soeurs" and "femmes fortes": Alternative Accounts of the Route

to Womanly Civic Virtue, and the History of French Feminism', in Clarissa 
Campbell Orr, ed., Wollstonecraft's Daughters: Womanhood in England and France 1780-1920 (Manchester: Manchester University Press, 1996), pp. 13550 .

, "La Charité est une Mère": Catholic Women and Poor Relief in France, 1690-1850', in Hugh Cunningham and Joanna Innes, eds, Charity, Philanthropy and Reform From the 1690s to 1850 (London: MacMillan Press Ltd, 1998), pp. 168-92.

Misner, Barbara, SCSC, 'Highly Respectable and Accomplished Ladies': Catholic Women Religious in America 1790-1850 (London: Garland Publishing, 1988).

Moore, Judith, A Zeal for Responsibility: The Struggle for Professional Nursing in Victorian England, 1868-1883 (Athens: University of Georgia Press, 1988).

Morgan, Susan, A Passion for Purity: Ellice Hopkins and the Politics of Gender in the Late-Victorian Church (Bristol: University of Bristol, 1999).

, 'Faith, Sex and Purity: The Religio-Feminist theory of Ellice Hopkins', Women's History Review, 9 (2000), 13-34. , 'Review', Gender \& History, 14 (2002), 163-5. , ed., Women, Religion and Feminism in Britain, 1750-1900 (Basingstoke: Palgrave Macmillan, 2002).

Mort, Frank, Dangerous Sexualities: Medico-Moral Politics in England since 1830 (London: Routledge \& Kegan Paul, 1987).

Mullins, Daniel J., 'The Catholic Church in Wales', in V. Alan McClelland and Michael Hodgetts, eds, From without the Flaminian Gate: 150 Years of Roman Catholicism in England and Wales 1850-2000 (London: Darton Longman \& Todd, 1999), pp. 272-94.

Mumm, Susan, "Not Worse than Other Girls": The Convent-Based Rehabilitation of Fallen Women in Victorian Britain', Journal of Social History, 29 (1996), 52746.

, Stolen Daughters, Virgin Mothers: Anglican Sisterhoods in Victorian Britain (London: Leicester University Press, 1998).

, “I Love my Sex”: Two Late Victorian Pulpit Women', in Joan Bellamy, Anne Laurence and Gill Perry, eds, Women, Scholarship and Criticism: Gender and Knowledge c. 1790-1900 (Manchester: Manchester University Press, 2000), pp. 204-21.

Murray, Janet, Strong-Minded Women: And Other Lost Voices from NineteenthCentury England (London: Penguin Books, 1984). Nelson, Claudia and Ann Sumner Holmes, 'Introduction', in Claudia Nelson and Ann Sumner Holmes, eds, Maternal Instincts: Visions of Motherhood and Sexuality in Britain, 18751925 (London: Macmillan Press, 1997), pp. 1-12.

Nelson, Sioban, Say Little, Do Much: Nurses, Nuns, and Hospitals in the Nineteenth Century (Philadelphia: University of Pennsylvania Press, 2001).

Nolan, Janet A., Ourselves Alone: Women's Emigration from Ireland, 1885-1920 (Lexington, Kentucky: University Press of Kentucky, 1989).

Norman, Edward R., Anti-Catholicism in Victorian England, Historical Problems: Studies and Documents (London: Allen and Unwin, 1968).

, The English Catholic Church in the Nineteenth Century (Oxford: Oxford University Press, 1984).

O'Brien, Susan, 'A Transatlantic Community of Saints: The Great Awakening and the First Evangelical Network 1735-1755', The American Historical Review, 91(1986), 811-32. 
, “Terra Incognita": The Nun in Nineteenth-Century England', Past and Present, 121 (1988), 110-40.

, '10,000 Nuns: Working in Convent Archives', Catholic Archives Journal, 9 (1989), 26-33.

, 'Lay-Sisters and Good Mothers: Working-Class Women in English Convents, 1840-1910', in W. J. Sheils and D. Wood, eds, Women in the Church: Papers Read at the 1989 Summer Meeting and the 1990 Winter Meeting of the Ecclesiastical History Society, Studies in Church History (Oxford: Ecclesiastical History Society, 1990), pp. 453-65.

, 'Women of the English Catholic Community: Nuns and Pupils at the Bar Convent, York, 1680-1790', in Judith Loades, ed., Monastic Studies: The Continuity of Tradition (Bangor, Gwynedd: Headstart History, 1990), pp. 26782.

, 'Making Catholic Spaces: Women, Décor, and Devotion in the English Catholic Church, 1840-1900', in Diana Woods, ed., The Church and the Arts (Oxford: Blackwell Publishers, 1992), pp. 449-64.

, 'Religious Life for Women', in V. Alan McClelland and Michael Hodgetts, eds, From without the Flaminian Gate: 150 Years of Roman Catholicism in England and Wales 1850-2000 (London: Darton Longman \& Todd, 1999), pp. 108-41.

, 'A Survey of Research and Writing about Roman Catholic Women's Congregations in Great Britain and Ireland' in Jan de Maeyer, Sophie Leplaie and Joachim Schmiedl, eds, Religious Institutes in Western Europe in the 19th and 20th Centuries (Leuven, Belgium: Leuven University Press, 2004), pp. 91116.

O'Connell, Marie, 'The Genesis of Convent Foundations and their Institutions in Ulster, 1840-1920', in Janice Holmes and Diane Urquhart, eds, Coming into the Light: The Work, Politics and Religion of Women in Ulster 1840-1940 (Belfast:The Institute of Irish Studies, 1994), pp. 149-201.

O'Day, Rosemary, The Professions in Early Modern England, 1450-1800: Servants of the Commonweal (London: Longman, 2000).

O'Dowd, Mary and Maryann Gialanella Valiulis, eds, Women and Irish History: Essays in Honour of Margaret MacCurtain (Dublin: Wolfhound Press, 1997).

O'Leary, Paul, 'From the Cradle to the Grave: Popular Catholicism among the Irish in Wales', in Patrick O'Sullivan, ed., Religion and Identity (London: Leicester University Press, 1996), pp. 183-95.

Orth, Clement, The Approbation of Religious Institutes (Washington, DC: The Catholic University of America, 1931).

O'Sullivan, Patrick, 'Introduction to Volume 5: Religion and Identity', in Patrick O'Sullivan, ed., Religion and Identity (London: Leicester University Press, 1996), pp. 1-24.

, 'Religion and Identity', in Patrick O'Sullivan, ed., Religion and Identity (London: Leicester University Press, 1996), pp. 183-95.

Patmore, Derek, The Life and Times of Coventry Patmore (London: Constable Publishers, 1949).

Paz, D.G., 'Anti-Catholicism, Anti-Irish Stereotyping, and Anti-Celtic Racism in Mid-Victorian Working-Class Periodicals', Albion, 18 (1986), 601-16. 
Pearce, Joseph, 'The Catholic Literary Revival', in V Alan McClelland and Michael Hodgetts, eds, From without the Flaminian Gate: 150 Years of Roman Catholicism in England and Wales 1850-2000 (London: Darton Longman + Todd, 1999), pp. 295-319.

Perkin, Harold, The Rise of Professional Society: England since 1880 (London: Routledge, 1989).

Perkin, Joan, Women and Marriage in Nineteenth Century England (London: Routledge, 1988).

Peterson, M. Jeanne, The Medical Profession in Mid-Victorian London (Berkeley: University of California Press, 1978).

Pinches, Sylvia, 'Church Charities in the Diocese of Birmingham, 1800-1918', Catholic Ancestor, 8 (2000), 28-36.

, 'Lay Charities in the Diocese of Birmingham, 1800-1918', Catholic Ancestor, 8 (2000), 73-82.

Poole, Myra, Prayer, Protest, Power: The Spirituality of Julie Billiart Today (Norwich: Canterbury Press, 2001).

Pooley, Colin, 'Segregation or Integration? The Residential Experience of the Irish in Mid-Victorian Britain', in Roger Swift and Sheridan Gilley, eds, The Irish in Britain 1815-1939 (London: Pinter Publishers, 1989), pp. 60-83.

Pope, Barbara Corrado, 'Immaculate and Powerful: The Marian Revival in the Nineteenth Century' in Clarissa W. Atkinson, Constance H. Buchanan and Margaret R. Miles, eds, Immaculate and Powerful: The Female in Sacred Image and Social Reality (Boston: Beacon Press, 1985), pp. 173-200.

Pope, Robert, 'Introduction', in Robert Pope, ed., Religion and National Identity : Wales and Scotland c.1700-2000 (Cardiff: University of Wales Press, 2001), pp. $1-13$.

Prest, Wilfrid, The Professions in Early Modern England (London: Croom Helm, 1987).

Prochaska, F.K., Women and Philanthropy in Nineteenth-Century England (Oxford: Clarendon Press, 1980).

Ranft, Patricia, A Woman's Way: The Forgotten History of Women Spiritual Directors (New York: Palgrave, 2000).

Rapley, Elizabeth, The Dévotes: Women and the Church in Seventeenth-Century France (London: McGill-Queen's University Press, 1990).

, A Social History of the Cloisters: Daily Life in the Teaching Monasteries of the Old Regime (Montreal: McGill-Queen's University Press, 2001).

Raughter, Rosemary, 'A Discreet Benevolence: Female Philanthropy and the Catholic Resurgence in Eighteenth-Century Ireland', Women's History Review, 6 (1997), 465-84.

Raymond, Janice, A Passion for Friends: Toward a Philosophy of Female Affection (London: The Women's Press, 1991).

Rendall, Jane, The Origins of Modern Feminism: Women in Britain, France and the United States 1780-1860 (London: Macmillan, 1985).

Reuther, Rosemary Radford, 'Catholic Women', in Rosemary Radford Ruether and Rosemary Skinner Keller, eds, In Our Own Voices: Four Centuries of American Women's Religious Writing (San Francisco: Harper San Francisco, 1995), pp. $17-60$. 
Rogers, Rebecca, 'Boarding Schools, Women Teachers and Domesticity: Reforming Girls' Secondary Education in the First Half of the Nineteenth Century', French Historical Studies, 19 (1995), 153-81.

, 'Schools, Discipline, and Community: Diary-Writing and Schoolgirl Culture in Late Nineteenth-Century France', Women's History Review, 4 (1995), 525-54.

, 'Retrograde or Modern? Unveiling the Teaching Nun in NineteenthCentury France', Social History, 23 (1998), 146-64. , 'French Education for British Girls in the Nineteenth Century', Women's History Magazine, 42 (2002), 21-9.

Rowbotham, Judith, "'Soldiers of Christ"? Images of Female Missionaries', Gender \& History, 12 (2001), 82-106.

, 'Ministering Angels, not Ministers: Foreign Missionary Movement, c. 1860-1910' in S. Morgan, ed., Women, Religion and Feminism in Britain, 17501900 (Houndmills: Palgrave Macmillan, 2002), pp. 179-96.

Rowlands, Marie B., 'Recusant Women, 1560-1640', in Mary Prior, ed., Women in English Society, 1500-1800 (London and New York: Methuen, 1985), pp. 149-80.

Savage, Michael, 'Space, Networks and Class Formation' in Neville Kirk, ed., Social Class and Marxism: Defences and Challenges (Aldershot, England: Scolar Press, 1996), pp. 58-86.

Scarisbrick, J.J., Selly Park and Beyond: The Story of Geneviève Dupuis and the Congregation of the Sisters of Charity of St Paul the Apostle (Selly Park, England: Sisters of Charity of St Paul the Apostle, 1997).

Semple, Rhonda A., Missionary Women: Gender, Professionalism and the Victorian Idea of Christian Mission (Suffolk: Boy dell \& Brewer, 2003).

Sharp, John, 'Juvenile Holiness: Catholic Revivalism among Children in Victorian Britain', Journal of Ecclesiastical History, 35 (1984), 220-38. , Reapers of the Harvest: The Redemptorists in Great Britain and Ireland, 1843-1898 (Dublin: Veritas, 1989).

Sheils, W.J., 'Catholicism from the Reformation to the Relief Acts', in Sheridan Gilley and W. J. Sheils, eds, A History of Religion in Britain: Practice and Belief from Pre-Roman Times to the Present (Oxford: Blackwell, 1994), pp. 234-51.

Sister Mary of St. Philip (Frances Mary Lescher) 1825-1904 (London: Longmans, Green and Co., 1922).

Smith-Rosenberg, Carroll, 'The Female World of Love and Ritual: Relations between Women in Nineteenth-Century America', in Carroll Smith-Rosenberg, ed., Disorderly Conduct: Visions of Gender in Victorian America (Oxford: Oxford University Press, 1985), pp. 1-29.

Smyth, Elizabeth, "Writing Teaching Us Our Mysteries": Women Religious Recording and Writing History', in Beverly Boutilier and Alison Prentice, eds, Creating Historical Memory: English-Canadian women and the Work, of History (Vancouver: UBC Press, 1997), pp. 101-28.

, 'Professionalization among the Professed: The Case of Roman Catholic Women Religious', in Elizabeth Smyth, Sandra Acker, Sandra Bourne and Alison Prentice, eds, Challenging Professions: Historical and Contemporary 
Perspectives on Women's Professional Work (Toronto: University of Toronto, 1999), pp. 234-54.

'Writing the History of Women Religious in Canada (1996-2001)', International Journal of Canadian Studies, 23 (spring 2001), 205-12.

Sneyd-Kynnersley, E.M., H.M.I. Some Passages in the Life of One ofH.M. Inspectors of Schools (London: Macmillan and Co., 1908).

Stanislaus, EM., Life of the Viscountess de Bonnault D'Houët: Foundress of the Society of the Faithful Companions of Jesus 1781-1858 (London: Longmans, Green and Co., 1913).

Steele, Francesca M., The Convents of Great Britain (London: Sands, and Dublin: M.H. Gill, 1902).

, Monasteries and Religious Houses of Great Britain and Ireland (London:

R. \& T Washbourne, 1903). , The Convents of Great Britain and Ireland (London: Sands, 1924).

Stone, Judith R, 'Anticlericals and Bonnes Soeurs: The Rhetoric of the 1901 Law of Associations', French Historical Studies, 23 (2000), 103-28.

Stone, Lawrence, The Past and the Present Revisited (London: Routledge \& Kegan Paul, 1981).

Suenens, Cardinal Leon Joseph, The Nun in the World: New Dimension in the Modern Apostolate (London: Burns \& Oates, 1962).

Sullivan, Mary C, RSM, Catherine McAuley and the Tradition of Mercy (Dublin, Ireland: Four Courts Press, 1995).

ed., The Correspondence of Catherine McAuley, 1818-1841 (Dublin, Ireland: Four Courts Press, 2004).

Summers, Anne, 'A Home from Home - Women's Philanthropic Work in the Nineteenth Century', in Sandra Burman, ed., Fit Work for Women (London: Croom Helm, 1979), pp. 33-63.

, 'Hidden from History? The Home Care of the Sick in the Nineteenth Century', History of Nursing Society Journal, 4 (1992-23), 227-43.

Supple, Jennifer R, 'Ultramontanism in Yorkshire, 1850-1900', Recusant History, 17 (1985), 274-86.

Tallett, Frank and Nicholas Atkin, Religion, Society and Politics in France since 1789 (London: Hambledon Press, 1991). , eds, Catholicism in Britain and France since 1789 (London: The Hambledon Press, 1996).

Thompson, Margaret S., 'Women, Feminism, and the New Religious History: Catholic Sisters as a Case-study', in Philip R. Vandermeer and Robert R. Swierenga, eds, Belief and Behaviour: Essays in New Religious History (New Jersey: Rutgers University Press, 1991), pp. 136-63.

Thorne, Susan, 'Missionary-Imperial Feminism', in Mary Taylor Huber and Nancy C. Lutkehaus, eds, Gendered Missions: Women and Men in Missionary Discourse and Practice (Ann Arbor, Michigan: University of Michigan Press, 1999).

Tihon, André, 'Les religieuses en Belgique du XVIIIe au XXe siècle: approche statistique', Revue Belge d'Histoire Contemporaine, 7 (1976), 1-54.

Valenze, Deborah, Prophetic Sons and Daughters: Female Preaching and Popular Religion in Industrial England (Princeton, New Jersey: Princeton University Press, 1985). 
Vicinus, Martha, A Widening Sphere: Changing Roles of Victorian Women (Bloomington and London: Indiana University Press, 1977).

, 'Distance and Desire: Rnglish Boarding-School Friendships', Signs, 9 (1984), 600-22.

, Independent Women: Work and Community for Single Women, 18501920 (London: Virago Press, 1985).

Walker, Claire, Gender and Politics in Seventeenth-Century English Convents: English Convents in France and the Low Countries (Basingstoke: Palgrave Macmillan, 2003).

Wallis, Frank H., Popular Anti-Catholicism in Mid-Victorian Britain (Lewiston, New York: The Edwin Mellen Press, 1993).

Walsh, Barbara, Roman Catholic Nuns in England and Wales, 1800-1937: A Social History (Dublin: Irish Academic Press, 2002).

Walsh, Michael J., 'Catholics, Society and Popular Culture', in V. Alan McClelland and Michael Hodgetts, eds, From without the Flaminian Gate: 150 Years of Roman Catholicism in England and Wales 1850-2000 (London: Darton Longman \& Todd, 1999), pp. 346-70.

West, Elizabeth A., One Woman's journey: Mary Rotter Founder - Little Company of Mary (Richmond, Victoria, Australia: Spectrum Publications, 2000).

[Wheaton, Louise], A Daughter of Coventry Patmore, Sister Mary Christina, SHCJ (London: Longmans, Green and Co., 1924).

Whitehead, Maurice, "Briefly, and in Confidence": Private Views of Her Majesty's Inspectors on English Catholic Elementary Schools, 1875', Recusant History, 20 (1991), 554-62.

Wilson, Linda, Constrained by Zeal: Female Spirituality amongst Nonconformists, 1825-1875 (Carlisle, England: Paternoster Publishing, 2000).

Witz, Anne, Professions and Patriarchy (London: Routledge, 1992).

Woodward, Kath, ed., Identity and Difference (London: Sage, 1997).

, Questioning Identity: Gender, Class, Nation (London: Open University Press, 2000).

Yeo, Eileen Janes, 'Social Motherhood and the Sexual Communion of Labour in British Social Science, 1850-1950', Women's History Review, 1 (1992), 63-88. , 'Some Contradictions of Social Motherhood', in Eileen Janes Yeo, ed., Mary Wollstonecraft and 200 Years of Feminisms (London: Rivers Oram Press, 1997), pp. 121-33.

, 'Protestant Feminists and Catholic Saints in Victorian Britain', in Eileen Janes Yeo, ed., Radical Femininity: Women's Self-representation in the Public Sphere (Manchester: Manchester University Press, 1998), pp. 127-48.

, 'The Creation of "Motherhood" and Women's Responses in Britain and France, 1750-1914', Women's History Review, 8 (1999), 201-18. 
Carmen M. Mangion - 9781526135285 